Bangladesh J. Bot. 44(4): 659-663, 2015 (December)

\title{
PHYSIOLOGICAL RESPONSE OF SWEET CORN (ZEA MAYS VAR. MERIT) TO FOLIAR APPLICATION OF SALICYLIC ACID UNDER WATER DEFICIT STRESS
}

\author{
Ebrahim Khalilvand Behrouzyar* and Mehrdad Yarnia \\ Department of Agronomy and Plant Breeding, Tabriz Branch, \\ Islamic Azad University, Tabriz, Iran \\ Key words: Physiological response, Salicylic acid, Sweet corn, Foliar application, \\ Water deficit stress
}

\begin{abstract}
The effect of water deficit stress and salicylic acid application on physiological characteristics of sweet corn (Zea mays var. Merit), an experiment was conducted. Treatments were water deficit stress in three levels: $\mathrm{a}_{1}$ : normal irrigation (100\% FC irrigation), $\mathrm{a}_{2}$ : fair stress ( $75 \% \mathrm{FC}$ irrigation) and $\mathrm{a}_{3}$ : mild stress $(50 \%$ FC irrigation). The second factor was the $0 / 1 \mathrm{mM}$ salicylic acid application in six levels $\left[\mathrm{b}_{1}\right.$ : control, $\mathrm{b}_{2}$ : seed priming, $b_{3}$ : SA application in 3 leaves stage, $b_{4}$ : SA application in pollination stage, $b_{5}$ : seed priming + SA application in pollination stage and $\mathrm{b}_{6}$ : SA application at 3 leaves stage + pollination stage. The analysis of variance showed significant effect of interaction between water deficit stress and SA application on Chl. a, Chl. b, Chl. a + b, 100-grain weight and ear yield $(p<0.01)$. Results showed that SA application at 3-leaves stage + pollination stage indicated five times more Chl.a as compared with control in $50 \% \mathrm{FC}$ irrigation. SA application at 3-leaves stage proved $4 / 2$ and $4 / 4$ times more Chl.b and Chl. a + b as compared to control in mild stress. SA application at pollination stage had the highest $(36 / 15 \mathrm{~g})$ and control at mild stress had the lowest (10/56 g) 100-grain weight. Also, SA application at 3-leaves stage + pollination stage had the highest $(245 / 1 \mathrm{~g} /$ plant $)$ and control at mild stress had the lowest (74/25 g/plant) ear yield.
\end{abstract}

\section{Introduction}

Salicylic acid (SA) or ortho-hydroxy benzoic acid is an important signalling molecule which is involved in plants response to wide range of environmental stresses (Senaratna et al. 2000, Rao et al, 2012). SA has been found to play a key role in seed germination, seedling establishment, cell growth, respiration, enhancement of enzyme activity, regulation of plant growth and development, interaction with other organisms and photosynthesis under adverse environmental conditions (Senaratna et al. 2000, Chen et al. 2012). Studies open a new window for the role to exogenous foliar application of SA in providing tolerance to the plants against various pathogens (Singh et al. 2004, Shah 2005). Studies reported that SA increased plant tolerance to several abiotic stresses, including salinity (Karlidag et al. 2009), drought (Hayat et al. 2008), osmotic stress (Mikoajczyk et al. 2000), heavy metal ( Zhou et al. 2009), uv radiation (Ervin et al. 2004) and temperature stress (Hashempour et al. 2014). Enhanced germination and seedling growth were recorded in wheat, when the grains were subjected to pre-sowing seed-soaking treatment in salicylic acid (Shakirova 2007). In another study, Khodary (2004) observed a significant increase in growth characteristics, pigment contents and photosynthetic rate in maize, sprayed with SA. The exogenous SA application also enhanced the carbohydrate content in maize. Flowering is another important parameter which is directly related to yield and productivity of plants. SA has been reported to induce flowering in a number of plants (Herrera-Tuz 2004, Larque-Saavedra and

*Author for correspondence: <e.khalilvand@iaut.ac.ir>. 
Martin-Mex 2007). Thus, it may be concluded that SA when applied acts as an regulator that potentially affects the growth and productivity in plants (Martin-Mex et al. 2005)

Previous studies suggested that SA may enhance the multiple types of stress tolerance in plants by interactive effects on several functional molecules. Thus, the objectives of this study were to investigate the effects of SA application on maize performance under different regimes of irrigation.

\section{Materials and Methods}

The field experiment was carried out in split plot form by completely randomized block design with three replicates at the Research Station of the Islamic Azad University, Tabriz Branch, north-western Iran, during 2014. The first factor was water deficit stress in three levels: $a_{1}$ : normal irrigation (100\% FC irrigation), a 2 : fair stress ( $75 \% \mathrm{FC}$ irrigation) and $\mathrm{a}_{3}$ : mild stress $(50 \% \mathrm{FC}$ irrigation). The second factor was the $0 / 1 \mathrm{mM}$ foliar application of salicylic acid in six levels $\left[\mathrm{b}_{1}\right.$ : control, $\mathrm{b}_{2}$ : seed priming, $\mathrm{b}_{3}$ : SA application in 3 leaves stage, $\mathrm{b}_{4}$ : SA application in pollination stage, $b_{5}$ : seed priming + SA application in pollination stage and $b_{6}$ : SA application in 3-leaves stage + pollination stage. Flooding irrigation was conducted and all of treatments were irrigated completely prior to $8-10$ leaves stage. Water deficit stress was imposed from $8-10$ leaves stage to physiological maturity. Each plot consists of 4 rows, $75 \mathrm{~cm}$ row spacing and 25 $\mathrm{cm}$ plant interval. There were $2-5$ seeds beside each other and they were thinned at three leaves stage to obtain plant density of 5 plants per $\mathrm{m}^{2}$.

To determine leaf chlorophyll concentration, one gram of the fresh leaf tissue was cut into small pieces and placed into a specimen bottle containing $10 \mathrm{ml}$ of absolute ethanol and stored in the dark for two weeks. One $\mathrm{ml}$ of the filtered extract was then diluted with $6 \mathrm{ml}$ of absolute ethanol and the absorbance of the chlorophyll solution measured using a spectrophotometer at 645 and $663 \mathrm{~nm}$. The chlorophyll $\mathrm{a}$ and $\mathrm{b}$ content and total chlorophyll $\mathrm{a}+$ chlorophyll $\mathrm{b}$ were estimated using the formula of Arnon (1949) as:

$$
\begin{aligned}
& \text { Chlorophyll a }(\mathrm{mg} / \mathrm{g})=0.0127 \text { A663 }-0.00269 \text { A645 } \\
& \text { Chlorophyll b }(\mathrm{mg} / \mathrm{g})=0.0029 \text { A663 }-0.00468 \text { A645 } \\
& \text { Total chlorophyll }(\mathrm{mg} / \mathrm{g})=0.0202 \mathrm{~A} 663+0.00802 \mathrm{~A} 645
\end{aligned}
$$

Ear yield was taken from three middle rows at the centre of each plot. Harvested ears were threshed and 100-grain weight was expressed.

In order to check the normality of data, analysis of variance, and mean comparison MSTAT$\mathrm{C}$ software were used. The means of the treatments were compared using the least significant difference (LSD) test at $\mathrm{p}<0.05$ (Palaniswamy and Palaniswamy 2005).

\section{Results and Discussion}

Results presented in Table 1 show that in fair stress (75\% FC irrigation), SA application at 3leaves stage + pollination stage indicated the highest Chl.a and SA application at 3-leaves stage proved the highest Chl. b, Chl. a + b, and control in mild stress (50\% FC irrigation) produced the lowest Chl. a, Chl.b and Chl. a + b (Table 2). It seems, in general, that chlorophyll concentration would be reduced certainly under severe and extended water stress, but it is possible to increase in fair stress, showing dependency of chlorophyll concentration response to environmental conditions and genotype (Boyer et al. 1987). Increased chlorophyll by fair stress may be is a result of increased specific leaf area and reduced leaf area due to reducing new cells size. As a consequence, leaf chlorophyll content increases upon exposure to fair stress because of larger cells per a leaf weight basis (Taiz and Zaiger 2006). The observed reduction of chlorophyll in water 
stressed plants may be due to a reduction in the lamellar content of the light harvesting chlorophyll $\mathrm{a} / \mathrm{b}$ protein (Randall et al. 1977). These results indicate SA foliar application can increase chlorophyll content. Similar results were obtained when plants of $B$. juncea were sprayed with lower concentrations $\left(10^{-5} \mathrm{M}\right)$ of SA, where, the chlorophyll content was significantly enhanced, whereas, higher concentrations proved to be inhibitory (Fariduddin et al. 2003). Moharekar et al. (2003) reported that salicylic acid activated the synthesis of carotenoids and xanthophylls and also enhanced the rate of deepoxidation with a concomitant decrease in chlorophyll pigments and chlorophyll a/b ratio in wheat and moong. Hayat et al. (2005) reported that the pigment content was significantly enhanced in wheat seedlings, raised from the grains pre-treated with lower concentration $\left(10^{-5} \mathrm{M}\right)$ of salicylic acid, whereas, higher concentrations did not prove to be beneficial. Besides seed-soaking treatment, the foliar application of SA also proved to be equally fruitful in increasing the pigment contents in Brassica napus (Ghai et al. 2002).

Table 1. Mean comparison of interaction between SA application and different regimes of irrigation.

\begin{tabular}{|c|c|c|c|c|c|c|}
\hline WDS & Treatments & $\begin{array}{l}\text { Chl.a } \\
\mathrm{mg} / \mathrm{g}\end{array}$ & $\begin{array}{l}\text { Chl.b } \\
\mathrm{mg} / \mathrm{g}\end{array}$ & $\begin{array}{c}\text { Chl.a + Chl.b } \\
\mathrm{mg} / \mathrm{g}\end{array}$ & $\begin{array}{l}\text { 100-grain } \\
\text { wt. (g) }\end{array}$ & $\begin{array}{l}\text { Ear yield } \\
(\mathrm{g} / \mathrm{plant})\end{array}$ \\
\hline \multirow[t]{6}{*}{$100 \% \mathrm{FC}$} & Control & 861 & 303 & 1164 & $21 / 80$ & $189 / 4$ \\
\hline & Seed priming & 1079 & 1130 & 2209 & $29 / 33$ & $228 / 5$ \\
\hline & 3-leaves stage & 1058 & 1107 & 2165 & $30 / 98$ & $166 / 4$ \\
\hline & Pollination stage & 741 & 797 & 1538 & $36 / 15$ & $136 / 3$ \\
\hline & Seed priming + pollination stage & 1058 & 713 & 1771 & $17 / 04$ & $121 / 6$ \\
\hline & $\begin{array}{l}\text { 3-leaves stage }+ \text { pollination } \\
\text { stage }\end{array}$ & 956 & 1057 & 2013 & $28 / 65$ & $245 / 1$ \\
\hline \multirow[t]{6}{*}{$75 \% \mathrm{FC}$} & Control & 788 & 740 & 1528 & $19 / 49$ & $93 / 76$ \\
\hline & Seed priming & 635 & 1177 & 1830 & $21 / 38$ & $116 / 4$ \\
\hline & 3-leaves stage & 1039 & 1224 & 2263 & $24 / 03$ & $158 / 4$ \\
\hline & Pollination stage & 858 & 1025 & 1883 & $28 / 60$ & $125 / 9$ \\
\hline & Seed priming + pollination stage & 557 & 623 & 1180 & $17 / 87$ & $88 / 20$ \\
\hline & $\begin{array}{l}\text { 3-leaves stage }+ \text { pollination } \\
\text { stage }\end{array}$ & 1090 & 948 & 2038 & $21 / 88$ & $129 / 8$ \\
\hline \multirow[t]{6}{*}{$50 \% \mathrm{FC}$} & Control & 215 & 290 & 505 & $10 / 56$ & $74 / 25$ \\
\hline & Seed priming & 644 & 405 & 1049 & $11 / 94$ & $86 / 93$ \\
\hline & 3-leaves stage & 628 & 750 & 1378 & $31 / 29$ & $93 / 60$ \\
\hline & Pollination stage & 234 & 1091 & 1325 & $15 / 58$ & $105 / 3$ \\
\hline & Seed priming + pollination stage & 364 & 1134 & 1498 & 12 & $84 / 58$ \\
\hline & $\begin{array}{l}\text { 3-leaves stage }+ \text { pollination } \\
\text { stage }\end{array}$ & 771 & 875 & 1646 & $16 / 73$ & $91 / 48$ \\
\hline LSD5\% & - & $46 / 61$ & $54 / 42$ & $78 / 69$ & $5 / 26$ & $30 / 65$ \\
\hline
\end{tabular}

WDS: Water deficit stress, FC: Field capacity.

Results presented in Table 2 showed that in normal irrigation, SA foliar application in pollination stage as compared to control in mild stress had significant effect on 100-grain weight. The application of 0/1 mM SA enhanced the 100-grain weight. In this respect, Arfan et al. (2007) studied the effect of exogenous application of SA through the rooting medium of two wheat cultivars differing in salinity tolerance. They found that increase in grain yield along with increase 
in 100-grain weight, number of grains and number of spikelets per spike with $0.25 \mathrm{mM} \mathrm{SA}$ application under saline conditions suggested that improvement in salt-induced reduction in grain yield with SA application was mainly due to increase in grain size and number.

The highest and lowest ear yield were observed in SA foliar application in normal irrigation and control in mild stress, respectively (Table 2). Ear yield of sweet corn is adversely affected by water deficit. Exogenous application of different chemicals may reduce stress induced inhibition of plant such as SA. Foliar application of SA can play an important role in reducing the effects of drought in maize (Rao et al. 2012. Under three irrigation treatments, ear yield was significantly enhanced with SA foliar application. Furthermore, the beneficial effect of SA on ear yield may be due to translocation of more photoassimilates to grains during grain filling, thereby increasing grain weight. These results are similar to those of Aldesuquy et al. (2012) who reported in SA application produced $9 \%$ more maize grain as compared to control treatment.

It may be concluded from the above discussion that salicylic acid acts as a potent regulator that can effectively modulate various plant growth responses. Exogenous application of SA enhanced the chlorophyll a, chlorophyll $\mathrm{b}$, total chlorophyll, 100-grain weight and ear yield under different irrigation regimes.

\section{Acknowledgement}

The authors would like to thank Tabriz Branch, Islamic Azad University for the financial support of this research, which is based on a research project contract.

\section{References}

Aldesuquy HS, Abbas MA, Abo-Hamed SA, Elhakem AH and Alsokari SA 2012. Glycine betaine and salicylic acid induced modification in productivity of two different cultivars of wheat grown under water stress. Stress Physiol. \& Biochem. 8 (2):72-89.

Arfan M, Athar HR and Ashraf M 2007. Does exogenous application of salicylic acid through the rooting medium modulate growth and photosynthetic capacity in two differently adapted spring wheat cultivars under salt stress? J. Plant. Physiol. 164(6): 685-694.

Arnon DI 1949. Copper enzymes in isolated chloroplasts, polyphenoxidase in beta vulgaris. Plant Physiology 24(1): 1-15.

Boyer JS, Armand PA and Sharp RE 1987. Light Stress and Leaf Water Relations. In: Photoinbibition. Kyle, D.J., C.B. Osmoud and C.J. Arntzen (Eds.). EIsevier Science Publishers BV Amsterdam. pp. 111-122.

Chen ZL, Li XM and Zhang H 2012. Effect of salicylic acid pretretment on drought stress resposes of zoysiagrass ( Zoysia japonica). Russian Plant Physiol. 61 (5): 619-625.

Ervin EH, Zhang XZ and Fike JH 2004. Ultraviolet-B radiation damage on KentuckynBluegrass II: hormone supplement effects. Hort Sci. 39 (6): 1471-1474.

Fariduddin Q, Hayat S and Ahmad A 2003. Salicylic acid influences net photosynthetic rate, carboxylation efficiency, nitrate reductase activity and seed yield in Brassica juncea. Photosynthetica. 41(2): 281-284.

Ghai N, Setia RC and Setia N 2002. Effects of paclobutrazol and salicylic acid on chlorophyll content, hill activity and yield components in Brassica napus L. (cv. GSL-1). Phytomorphology 52: 83-87.

Hashempour A, Ghasemzhad M, Ghazvini F and Sohani MM 2014. The physiological and biochemical response to freezing stress olive plants treated with salicylic acid. Russian Plant Physiol. 61 (4): 443 450.

Hayat S, Fariduddin Q, Ali B and Ahmad A 2005. Effect of salicylic acid on growth and enzyme activities of wheat seedlings. Acta Agron. Hung. 53: 433-437.

Hayat S, Hasan SA, Fariduddin Q and Ahmad A 2008. Growth of tomato (Lycopersicon esculentum) in response to salicylic acid under water stress. J. Plant Int. 3 (4): 297-304. 
Herrera-Tuz R 2004. Reguladores de crecimiento XXI. Efecto del acido salicilico en la productividad de papaya maradol (Carica papaya L.). Tesis de Licenciatura Instituto Tecnologico Agropecuario, Conkal, Yucatan, Mexico.

Karlidag H, Yildirim E and Turan M 2009. Salicylic acid ameliorates the adverse effect of salt stress on strawberry. J. Agric. Sci. 66: 271-278.

Khodary SFA 2004. Effect of salicylic acid on the growth, photosynthesis and carbohydrate metabolism in salt stressed maize plants. Int. J. Agric. Biol. 6: 5-8.

Larque-Saavedra A and Martin-Mex R 2007. Effects of salicylic acid on the bioproductivity of the plants. In: Hayat, S., Ahmad, A. (Eds.), Salicylic Acid, A plant Hormone. Springer Netherlands Publisher. pp. 15-23.

Martin-Mex R, Nexticapan-Garces A and Larque-Saavedra A 2005. Effect of salicylic acid in sex expression in Carica papaya L. In: 10th International Symposium on Plant Biorregulators in Fruit Production, June 26-30 de 2005. Saltillo, Coahuila, Mexico. p. 113.

Mikoajczyk M, Awotunde OS, Muszynska G, Klessig DF and Dobrowolska G 2000. Osmotic Stress Induces Rapid Activation of a Salicylic Acid - Induced Protein Kinase and a Homolog of Protein Kinase ASK1 in Tobacco Cells. The Plant Cell 12: 165-178.

Moharekar ST, Lokhande SD, Hara T, Tanaka R, Tanaka A and Chavan PD 2003. Effect of salicylic acid on chlorophyll and carotenoid contents of wheat and moong seedlings. Photosynthetica 41: 315-317.

Randall SA, Thornber P and Fiscus E 1977. Water stress effects on the content and organization of chlorophyll in mesophyll and Bundle sheath chloroplasts of maize. Plant Physiol. 59: 351-353.

Rao SR, Qayyum A, Razzaq A, Ahmad M, Mahmood I and Sher A 2012. Role of foliar application of salisylic acid and L- Tryptophan in drought tolerance on maize. The J. Animal \& Plant Sciences 22 (3): 768-772.

Senaratna T, Touchell D, Bunn E and Dixon K 2000. Acetyl salicylic acid (aspirin) and salicylic acid induce multiple stress tolerance in bean and tomato plants. Plant Growth Regul. 30: 157-161.

Shah J 2005. Lipids, lipases and lipid modifying enzymes in plant disease resistance. Annu. Rev. Phytopathol. 43: 229-260.

Shakirova FM 2007. Role of hormonal system in the manisfestation of growth promoting and anti-stress action of salicylic acid. In: Hayat, S., Ahmad, A. (Eds.), Salicylic Acid, A Plant Hormone. Springer Netherlands Publisher. pp. 69-89.

Singh DP Moore CA Gilliland and A Carr JP 2004. Activation of multiple antiviral defense mechanisms by salicylic acid. Mol. Plant Pathol. 5: 57-63.

Makoto TB, Carver BF, Johnson RC and Smith EL (1990). Relationship between water content and grain yield during reproductive period in winter wheat. Euphytica 49: 255-262.

Palaniswamy UR and Palaniswamy KM 2005. Handbook of statistics for teaching and research in plant and crop science. CRC Press. pp. 624.

Taiz L and Zeiger E 2006. Plant Physiology. 3rd Ed., Sinauer Associates, Sunderland, MA. pp. 705.

Zhou ZS, Guo K, Elbaz AA and Yang ZM 2009. Salicylic acid alleviates mercury toxicity by preventing oxidative stress in roots of Medicago sativa. Environ. Exp. Bot. 65: 27-34.

(Manuscript received on 31 May, 2015; revised on 11 October, 2015) 